\title{
MB21D2 wt Allele
}

National Cancer Institute

\section{Source}

National Cancer Institute. MB21D2 wt Allele. NCI Thesaurus. Code C132171.

Human MB21D2 wild-type allele is located in the vicinity of 3q29 and is approximately $121 \mathrm{~kb}$ in length. This allele, which encodes protein MB21D2, may be involved in adherens junction functions. 